DOI: $10.17951 / f f .2018 .36 .2 .121-129$

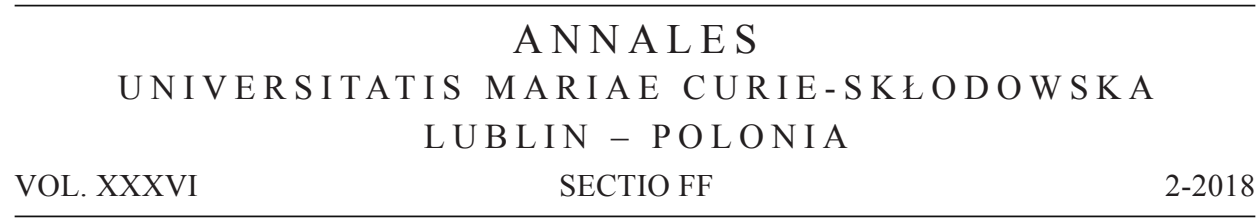

\author{
ZBIGNIEW MAZUR \\ Uniwersytet Marii Curie-Skłodowskiej \\ ORCID ID: https://orcid.org/0000-0002-9134-0005
}

\title{
Regeneration Through Violence? The American Family in Ray Donovan and Big Little Lies
}

Odrodzenie przez przemoc? Rodzina amerykańska

w serialach Ray Donovan i Wielkie kłamstewka

In his famous "Regeneration Through Violence" thesis, from the first volume of his trilogy on the mythology of the American West published in 1973, Richard Slotkin states that violence has a fundamental significance for the creation of American mythogenesis. He argues that "the myth of regeneration through violence became the structuring metaphor of the American experience" (5). What makes the myth "distinctively 'American' is [...] the mythic significance we have assigned to the kinds of violence we have actually experienced" (13).

Slotkin's book is a methodical study of the creation and development of this myth in early legends of the frontier and in $19^{\text {th }}$-century American literature. Looking for the roots of American values and traditions, the author finds their origin in the fears and anxieties of European settlers, who, laying a claim to a new world, which they interpreted as a wilderness, displaced Native Americans. According to the logic of the thesis, the heroes of early American narratives, such as David Boone and Deerslayer, enter the wilderness in search of self-renewal. In Slotkin's words, the "myth of the hunter [...] is one of self-renewal or self-creation through acts of violence" (1973:556). Thus, the American myth begins with a hero who lives in a state of innocence. The stability of life is endangered by corruption, which in the early narratives was often embodied by Indians, who inhabited the wilderness and were supposed to represent the protagonist's evil instincts. Then, in the next stage of the narrative, the hero commits violent acts directed against Indians to begin his 
"figurative rebirth" and to create himself anew. Thus, violence and destruction of the wilderness lead to its regeneration, and the regeneration of the hero (Slotkin, 1973:305,101).

The myths present at the foundation of the American nation have continued to evolve in American society until the present day. American popular culture is this area in which the national myths are continually revoked, reassessed and redefined in a new context of the moment. Richard Slotkin himself pointed to the responsiveness of popular culture to the influence of mythical narratives in his generic analysis of The Charge of the Light Brigade (1936, dir. Michael Curtiz) (Slotkin, 1990) and in his study of the ideological power of Black Hawk Down (2001, dir. Ridley Scott) in post 9/11 America (Slotkin, 2017).

Several scholars investigate how the topos of "regeneration through violence" has been continually evoked in popular film and television genres such as western (Castleberry, 2014), horror (Tenga and Bassett, 2016), cop cinema (Durys, 2016), and action cinema (Lichtenfeld, 2004; Purse, 2011). These authors claim that the traditional myth, as defined by Slotkin, was continuously and creatively used in $20^{\text {th }}$-century cinematic genres. The American hero, finding himself in the wilderness, represented by the West, a criminal underworld, or a post-apocalyptic zombie land, succeeds only when he commits some violent acts. Eric Lichtenfeld concludes, for example, that the conventional narrative of action films shows the protagonist committing violence against the Other to regenerate his environment and restore social and moral order, in a celebrated re-establishment of the status quo (2004:61).

While popular in the $20^{\text {th }}$ century, the motif of regenerative violence in texts of popular culture became especially meaningful in the cultural and political climate of the post 9/11 America. It was after the events of 9/11 that America witnessed a re-affirmation of the belief in the power of violence while the "War on Terror" has been waged. The belief that violence should play a principal role in American reactions to both local and global challenges has been widespread in the 2010s, when future of individuals and nations seems so uncertain. The myth of the innocence, its corruption, and its possible redemption through violence remains a valid part of American identities.

In this paper I discuss two recent American TV shows in order to re-assess the continuity of the "regeneration through violence" myth and to study its creative transformations within major discourses of contemporary American culture. The two shows belong, roughly speaking, to hybrid forms of TV crime drama. The first one is Showtime's series Ray Donovan (2013-2018), which follows the fortunes of its eponymous character (played by Liev Schreiber), a "fixer", who is extremely gifted at solving problems of the LA elite, but fails in his attempts to build a safe and stable Californian haven for his own dysfunctional Boston "Southie" family. 
Spanning six seasons (the sixth one opened in October 2018), the narrative of the series centers on the exploits of Ray, who, ingeniously using combinations of persuasion, bribery, extortion, blackmail and outward violence, rescues morally corrupt LA celebrities from crisis situations.

HBO mini-series Big Little Lies (2017), based on a book by Liane Moriarty, tells a story about a group of women from northern California, who are members of an ostensibly liberal and progressive social elite. Although they present themselves to each other as liberated, happy, and self-satisfied persons, each of the women is troubled by family problems. They are rich, but their comfortable, well-ordered life in a respectable community is only an illusion and a pose maintained for the benefit of appearances. As the film's narrative develops, numerous conflicts are identified. The main storyline is delivered in the form of extended retrospections, while the current timeline is made up of short vignettes, where secondary characters, members of the school community, are interviewed in the course of a police investigation into a mysterious killing. Big Little Lies ingeniously uses the code of enigma, typical for a detective drama, with a twist: neither the identity of the perpetrator, nor that of the victim is revealed until the season's finale.

What links the two shows is that they both combine the conventions of crime drama and family drama, with violence being both the source of narrative conflicts and a tool for their settlement. The concept of the family is important enough on its own, but, within the larger American mythology, it may have a wider cultural significance. For example, William Handley (2002:14) claims, discussing $20^{\text {th }}$-century western novels, that literary representations of western marriages are "competing allegories of national identity". Handley states that "the popularly embraced fiction [...] is filled not with examples of free individualism but with forced choices and constraints, tragic marriages, environmental hardships, group conflict and identity confusion, murder, failure, and accidents" (24). In his view marriage is represented in literature as an equivalent of national union. Without evoking Slotkin's concepts, Handley shows how a study focused on marriage and violence reveals the ideological "complications" of popular westerns (225).

I assume that similar "ideological complications" may be exposed when the motif of violence is investigated in $21^{\text {st }}$-century crime/family dramas. In Ray Donovan violence is the purgative force through which the hero attempts to put his traumatic Boston past behind and build a new, safe and prosperous life for his family. Ray lives off violence, he is good at using it in an effective way, although he also sometimes happens to find himself at the receiving end. He prefers to act on his own, keeping the ugly side of his business away from his wife and children.

Actually, one can see numerous analogies between the character of Ray Donovan and the western's figure of the gunslinger, a lonely individual who 
dirties his hands on behalf of the community, rescues and reinvigorates it at the end of the narrative. Ray's figure is a modern Californian rendition of a gunslinger for hire. He is a Lone Ranger complete with his two sidekicks, reminiscent of original Tonto. Ray's assistants are both "Othered"; Israeli hard man Avi (Steven Bauer), by his ethnicity, and lesbian computer wizard Lena (Katherine Moennig), by her sexuality.

Richard Slotkin (1973) argues that The Frontier Myth is characterized by three movements: separation, regression and conflict. In Ray Donovan the separation state is the relocation of the Donovans to California, a place which is safer and more comfortable to live, but at the same time a location which is morally degenerate. The Donovans want to break from the criminal past of their life in Boston. However, California becomes their mythical wilderness, in which Ray and his brothers embrace primal urges and instincts, and engage in conflicts, the ultimate purpose of which is - as strange as it may sound - to save the family. In the original myth conflicts would have a purgative function: the hunter-hero fights against the Indians and the wilderness, and violence that leads to his regeneration. Metaphorically, the mythical hero becomes Indian for the purpose of destroying the Indian (Slotkin, 1973:11). Ray Donovan, fighting for family happiness, fiercely protective of his wife and young daughter and son, becomes as violent as the corrupt people he works for or fights against. He carries the burden of brutality, dirt, and vice of the people he is working for, hoping to achieve regeneration at the end of his quest.

Ray Donovan, however, is a gunslinger with a difference - not only because he is never been a moral paragon in his life: he is an alcoholic, notoriously unfaithful to his wife, Abby (Paula Malcomson). Contrary to the mythical lone ranger, at the end of his mission he is not supposed to ride away, but to stay in the community he would save, become a homesteader, happily enjoying the fruits of his violent labours. Ray is first of all the head of his troublesome family, which consists also of his brothers. The Donovans have a long and turbulent history to put behind. Two brothers suffered from child abuse. As adults, they all got involved in crime and drugs. The elder brother, Terry (Eddie Marsan) has Parkinson's disease. Periodic depression afflicts several members of the family, including Ray himself.

Family conflicts exist on several levels. Abby is a strong-willed and demanding wife, who wants to build a real, traditional home. The teenage children, Bridget (Kerris Dorsey) and Conor (Devon Bagby) experiment with their own audacious lives. The complications multiply when Mickey (Jon Voight), the Donovans' father, enters the scene, having spent twenty years in jail. Ray has to intervene on behalf of those he loves, and the viewers may actually feel exhausted by his Sisyphean efforts to patch up problems in his family and to save his relatives from the troubles they continually bring upon themselves. 
There is also violence within the family - Ray is so desperate to get rid of his scheming, erotomaniac, manipulative, and megalomaniac father that he makes arrangements for his arrest, and even for his murder. In season five Ray attends anger management sessions after some violent event, which only later is revealed to have been a brutal fist fight with the father and the brothers, one of whom Terry - assisted Ray's cancer-stricken wife in suicide. At the end of the fifth season of Ray Donovan, the hero has nothing left to do. He has completed the tasks on behalf of his clients. In the last scenes of episode 12, he follows the ghost of Abby to the roof of a New York building. When she falls back off the building, he stands there for a moment and then he falls forward himself.

Although numerous elements typical for a conventional Western fiction can be identified in the narrative of the series, Ray Donovan is a story about "action without regeneration". Violence is not recuperative as it fails to bring restoration of social and moral order. The series' narrative is not finished yet, as the sixth season has just opened, but there is nothing unique about the show's bleak and twisted interpretation of the regeneration myth. Ray Donovan is representative of these American action narratives which lean towards "deracination, disorder, and apocalypse" (Mattes, 2014:189). It tells the story about a hero who uses violence to save his family, but his actions have no ultimate outcome, and his victories turn out to be meaningless. The series is an example of an "action without regeneration" narrative, where the main protagonist, contrary to the hero of the "regeneration through violence" myth, is constructed through a relationship to action itself rather than through the outcome of that action (Mattes, 2014:189).

Ray Donovan narrates the story of a tragic hero who puts up a futile fight to preserve his family. When we consider the model of the family this TV drama endorses, we get a complicated, unequivocal picture, within which, however, the impact of a paternalistic, neo-conservative discourse with some misogynistic overtones is easily discernible. The series focuses on a dream about a traditional extended family with Catholic roots, where a powerful, dominant male figure placed in the center attempts to control the lives of his wife, his children, and his brothers in a frantic attempt to make all of them happy.

Big Little Lies seems to be an opposite case. The story, set in Monterey, pictures the environment which is extremely progressive, tolerant, and open, even if not very much ethnically diversified. The world is presented from a female perspective. The main protagonists, five women brought together by social ties, the strongest of which is the fact that their children attend the same school, are intelligent, strong, well-educated, with a potential for domineering. The neighbourhood is rich, enjoys a privileged status, symbolized by their ocean side glass houses, and classy interior decorations. The community seems to take for granted 
the achievements of feminism. Not all of the women work out of home, but the female protagonists are socially active: they compete in fund-raising, volunteering, and charity work. They are all pre-occupied with the ways in which their kids are educated, with home, and with the community, as dictated by the norms of new middle-class femininity, which they seem to whole-heartedly embrace. Complications begin when Jane (Shailene Woodley), a single mom barely keeping her head above water, arrives at the scene. Her appearance brings many hidden tensions into the open.

The real topic of this TV drama is violence, which, officially rejected and condemned, is vividly present under the façade of politically correct life of this affluent Californian community. Jane, who becomes Madeline's (Reese Witherspoon) confidante and friend, was raped by a stranger, and her son, Ziggy (Iain Armitage) was the result of the crime. Jane, coping with her trauma, is fixated on revenge. Unable to forgive, she strives to identify the rapist and is ready to kill him. In a parallel development, Jane's son, first-grader Ziggy, is blamed for being a school bully. The accusations divide the community, divided into those who believe Ziggy is innocent and those who side with the girl accusing him.

Finally, there is the question of domestic violence. Perry (Alexander Skarsgård), the abusive husband of Celeste (Nicole Kidman), changed their passionate love into a relationship marked by repetitive violence. He is a handsome brute who cannot control his anger and jealousy. What triggers the violent assaults are his wife's attempts to gain more independence in their relationship. Despite that, Celeste keeps up the pretenses of being happily married, using psychological repression to normalize the fact that she is a regular victim of physical abuse. She continues to blame herself for the abuse, and is ready to suffer as long as her family is saved and her husband's brutality does not affect their twin sons.

In the season's finale the viewers find out that the bully at the school was actually Max, one of Perry and Celeste's twin sons. Celeste realizes that she was not able to protect her children from Perry's violence: Max has copied his father's behavior. It is also revealed, in a dynamically filmed, frantic sequence happening at a posh school fundraiser, that the victim of the murder which is investigated in the series was no one else but Perry. Perry turned out to have been Jane's rapist, which she realized witnessing his violent assault on Celeste, and which she wordlessly communicated to the other women. Perry died pushed down a stairway by Bonnie (Zoë Kravitz), the young wife of Madeleine's former husband Nathan (James Tupper). Bonnie is a yoga instructor, the most righteous, liberal and progressive character of the show, a post-hippie, fragile, tolerant and empathetic woman. The narrative of Big Little Lies suggests, however, that all the five women had their hand in this act, which is not only retributive, but also strongly recuperative. 
The violent finale offered a - paradoxically - peaceable conclusion to all the dramatic subplots of the series. It allowed the five women to finally put an end to the conflicts which separated them from one another. In the short scenes, most of which are shown without audio, the women are being interviewed by the police. The viewers can easily deduce that they are telling the same story, explaining that Perry's death was a tragic accident. The scenes of Perry's funeral, peaceful and unemotional, suggest a restoration of social order. This picture of the regeneration of the community and the families is completed with the final idyllic scenes at a beach where the five major female protagonists - all feuds put aside - are playing with their children, with no adult males being present. The white waves suggest that the act of violence in which all the women took part had a purifying effect. The scene is illustrated by a tranquil rendition of Rolling Stones" "You Can't Always Get What You Want" (by band Ituana), where the lyrics end with the optimistic phrase "but you get what you need". The concluding scenes suggest that the act of violence which brought a resolution to the narrative conflicts was an act of necessity, even if it did not bring a happy end to the story. The protagonists are safe and free, even though they are aware that their lives will never be as peaceful and untroubled as they once hoped.

If we apply the myth of "regeneration through violence" to Big Little Lies, the narrative of this TV drama does have its wilderness, inhabited by the abusive male, a dangerous brute who cannot control his emotions, who is degenerate and destructive. However, there is no one who would be an analogy to a hunter-hero: a single, violent, male character, who would be able to descend into the wilderness to defend his community. Instead, it is a single act of violence, committed by the most unlikely protagonist, which fortuitously, but contrary to the values of the community, has a recuperative and restorative power, bringing about peace and social order. The heroines of the series all partake in this act of violence, which, in a mythical fashion, is linked to social regeneration. However, the strongly masculine and individualistic elements ascribed to the hero of the original myth are missing in the gripping narrative of Big Little Lies.

Ostensibly, the two shows are very different in their discursive treatment of the American family. Nevertheless, although rooted in dissimilar ideological foundations and different in their generic forms, both shows focus on violence as an underlining theme and the prime cause of crises in the American family. Both narratives can be interpreted as creative re-workings of the "regeneration through violence" myth. Both refer to the mythical notion of "regeneration of violence", but they undermine and subvert the traditional American myth (Ligor (2017) offers similar conclusions in his analysis of No Country for Old Men). In its dramatic retelling of the myth of a hunter/gunslinger, Ray Donovan persistently 
and persuasively points to the futility of the use of violence in Ray's struggle to save and preserve the family. On the other hand, the female-centered narrative of Big Little Lies, despite its liberal and feminist foundations, seems to imply that retributive violence can indeed have a cathartic and regenerative function.

\section{BIBLIOGRAFIA PODMIOTOWA}

Vallée, J.-M. (prod.) (2017-2018). Big Little Lies (TV series). HBO.

Zuriff, B., Gordon, M., Biderman, A. (prod.) (2013-2018). Ray Donovan (TV series), seasons 1-6. Showtime.

\section{BIBLIOGRAFIA PRZEDMIOTOWA}

Castleberry, GL. (2014). Revising the Western: Connecting Genre Rituals and American Western Revisionism in TV's Sons of Anarchy. Cultural Studies $\leftrightarrow$ Critical Methodologies, 14(3), pp. 269-278.

Durys, E. (2016). Kulturowy wymiar amerykańskiego kina policyjnego (Cultural Dimension of American Cop Cinema). In: T. Domański (ed.), Międzynarodowe studia polityczne i kulturowewobec wyzwań wspótczesności (pp. 327-346). Łódź: Wydawnictwo Uniwersytetu Łódzkiego.

Handley, W. (2002). Marriage, Violence, and the Nation in the American Literary West. New York: Cambridge University Press.

Lichtenfeld, E. (2004). Action Speaks Louder: Violence, Spectacle, and the American Action Movie. Westport \& London: Prager.

Ligor, J. (2017). The Character of Anton Chigurh in the Coen Brothers No Country for Old Men as an Expression of Reflections on Evil and Violence. Społeczeństwo. Edukacja. Język, 5, pp. 73-86.

Mattes, A. (2014). Action without Regeneration: The Deracination of the American Action Hero in Michael Mann's Heat. Journal of Popular Film and Television, 42(4), pp. 186-194.

Purse, L. (2011). Contemporary Action Cinema. Edinburgh: Edinburgh University Press.

Slotkin, R. (1973). Regeneration through Violence: The Mythology of the American Frontier, 1600 1860. Middletown: Wesleyan University Press.

Slotkin, R. (1990). The Continuity of Forms: Myth and Genre in Warner Brothers' The Charge of the Light Brigade. Representations, 29, pp. 1-23.

Slotkin, R. (2017). Thinking Mythologically: Black Hawk Down, the "Platoon Movie" and the War of Choice in Iraq. European Journal of American Studies, 12(2), pp. 1-18.

Tenga, A., Bassett, J. (2016) "You Kill or You Die, or You Die and You Kill”: Meaning and Violence in AMC's The Walking Dead. The Journal of Popular Culture, 49(6), pp. 1280-1300.

\section{ABSTRAKT}

Celem pracy jest zbadanie, jak mitologiczny motyw odrodzenia przez przemoc, który Richard Slotkin opisał jako „metaforę nadająca strukturę amerykańskiemu doświadczeniu”, jest wykorzystywany we współczesnej amerykańskiej kulturze popularnej. Artykuł przedstawia obrazy rodziny w dwóch amerykańskich serialach telewizyjnych: serialu kryminalnym Ray Donovan (2013-2018, Showtime) i miniserialu Wielkie kłamstewka (Big Little Lies, HBO, 2017). Analiza narracji w omawianych 
tekstach filmowych pokazuje, że oba twórczo wykorzystują motyw odrodzenia przez przemoc. Chociaż narracje te osadzone są w różnych założeniach ideologicznych i reprezentują inne gatunki telewizyjne, w obydwu najważniejszy temat to przemoc jako główna przyczyna kryzysów w rodzinie. Przedstawienie rodziny w serialu Ray Donovan zbudowane jest w obrębie paternalistycznego, neokonserwatywnego dyskursu. Obraz ten opowiada o losach bohatera, który skutecznie zajmuje się wybawianiem z kłopotów przedstawicieli bogatej i niemoralnej elity Los Angeles, ale który nie radzi sobie z rozwiązywaniem problemów swojej dysfunkcjonalnej rodziny. Wielkie kłamstewka to historia pięciu kobiet z północnej Kalifornii należących do ostentacyjnie liberalnej i postępowej elity społecznej. Każda z nich musi się jednak zmierzyć z poważnymi problemami rodzinnymi. Niniejsze badanie dowodzi, że choć narracje w obydwu serialach podporządkowane zostały tematowi odrodzenia przez przemoc, to ich wymowa znacznie się różni. Ray Donovan konsekwentnie pokazuje, jak bezowocne i nieskuteczne jest uciekanie się do przemocy w próbach uratowania rodziny. Narracja w Wielkich kłamstewkach, chociaż osadzona w progresywnym i liberalnym dyskursie, zdaje się wskazywać, że przemoc, jako kara za zło, może prowadzić do katharsis i odrodzenia.

Słowa klucze: przemoc, odrodzenie przez przemoc, rodzina amerykańska, amerykańskie seriale telewizyjne, Ray Donovan, Wielkie klamstewka

\begin{abstract}
The aim of the paper is to assess the continuity of the mythical motifs of "regeneration through violence", famously described by Richard Slotkin as "the structuring metaphor of the American experience", in contemporary American popular culture. The article discusses the representations of family in two American television dramas: Showtime's television crime drama series Ray Donovan (2013-2018) and HBO mini-series Big Little Lies (2017). The narrative analysis of the two shows reveals that both dramas creatively employ the theme of "regeneration through violence". Although rooted in two different ideological foundations and different in their genres, both shows focus on violence as an underlining theme and the prime cause of the crises in the family. A model of the family framed within a paternalistic, neo-conservative discourse is offered in Ray Donovan. Its eponymous character is successful at solving problems of the LA rich and immoral elite, but hopeless in dealing with those created by his own dysfunctional family. Big Little Lies tells the story of five women from northern California, members of an ostensibly liberal and progressive social elite, each of which is, however, troubled by the serious problems of their respective families. The analysis shows that although the narratives of both series are structured along the theme of "regeneration through violence", their meanings are strikingly different from each other. Ray Donovan persistently points to the futility of the use of violence in its characters' struggle to save and preserve the family, while the narrative of Big Little Lies, despite its progressive overtones, seems to imply that retributive violence can indeed have a cathartic and regenerative function.
\end{abstract}

Keywords: violence, regeneration through violence, American family, American TV dramas, Ray Donovan, Big Little Lies 